\title{
Usage of Digital Payments - Pre and Post Demonetization
}

\author{
G. Maheswari, Justin Thomas Philip
}

\begin{abstract}
Emerging changes of ICT (Information and Communications Technology) and the impact of demonetization accelerated various digital initiatives. Demonetization focuses on increasing usage of digital transactions in all the areas. This helps to investigate the usage pattern of digital payments before and after demonetization. The outcome of the study shows that using E-Wallets, Mobile app, net banking, credit card, and debit card has increased after demonetization and using of cheque has decreased after demonetization. This shows that the people adapted to the digital payment system because the technology made them with ease.
\end{abstract}

Keywords: Digital Payment System, Demonetization, Cashless Transactions, Digital Wallets, E-Payments and online payments.

\section{INTRODUCTION}

$\mathrm{U}$ sage of alternative channels in banking has been increased due to demonetization Digital payments are a system where no physical cash is involved in the transaction. Payments are made through electronically.

Statistics shows that the number of smart phone users in India will increase tremendously in the near future. That growth will influence the digital payments in a positive way. As per data available with the RBI and National Payments Corporation of India (NPCI), the proliferation in digital payments has been reflective in common channels such as National Electronic Fund Transfer (NEFT) and mobile banking in the period of September 2016 to September 2018. During the period NEFT dealings had improved from Rs. 988,000 crore to Rs14,182,000 crore in 2017 and then raised to Rs18,015,000 crore in 2018. The rate of mobile banking transactions, too, shot up from Rs2,700 crore in September 2015 to Rs104,300 crore in 2016, and to Rs186,200 crore in 2017.SBI has also reported a 502 bps increase in the share of alternative channels at 83.47 per cent as on September 2018 against 78.45 per cent in the year-ago period.

\section{REVIEW OF LITERATURE}

P. Jijin, (2019) found the usage of cards for transactions

Revised Manuscript Received on December 05, 2019.

* Correspondence Author

Dr. G. Maheswari*, Assistant Professor, Department of Commerce ShiftII, Madras Christian College, Chennai, India.

E-mail: maheswarimsu@gmail.com

Justin Thomas Philip, Assistant Professor, Department of Commerce Shift- II, Madras Christian College, Chennai, India.

E-mail: justinthomas619@gmail.com has increased and demonetization push people to switch to digital transactions. Prasad Rajendra Byakod et.al (2018) conducted a study to know the people's insight about Digital Payment System and the variables that impact the customers' adoption of electronic payment services. The author opined that the lack of training on use of DPS as the major reason for less adoption of the system. Shamsher Singh and Ravish Rana (2017) the result shows that acceptance of digital payment is influenced by the education level of the customer and high usage of Smartphone and internet penetration in metropolitan area also facilitated the adoption of digital payment. Ms. Sunandan Bumra (2017) the main findings were, the automobile sector saw a short term impact where the purchases were delayed due to scarcity of funds, but was neutral for purchases through financing or banked cash. Veerakumar .K. (2017) demographic variables namely gender, age, annual income, occupation have significant association with the impact of demonetization electronic payment methods have been increased and this will shift an efficient cashless infrastructure. Gangopadhayay (2009) opined that infrastructure is one of the main influencing factors or the effective implementation of cashless economy in the country.

\section{RESEARCH GAP AND OBJECTIVES OF THE STUDY}

As extracted from the review of literature, we found that many of the researchers studied that the influence of demonetization on several prominent segments of Indian economy and people. Some study shows that perception towards digital payment mode, usage of digital wallets and its impact. There is no research papers related to comparative study with regarding to the usage of digital payments with respect to before and after demonetization.

This study focus on a comparative study on practice of digital payments with regard to pre and post demonetization with an objective to analyze the preference, commencement, frequency and purpose of using digital payments.

\section{A. Source of Data}

- The main data collected by using questionnaire from 232 respondents in Chennai.

- Secondary data collected from various research articles, journal, magazines and books

Published By:

Blue Eyes Intelligence Engineering 


\section{RESULTS AND DISCUSSIONS}

Table - 1: Frequency Distribution for Demographic Outline of the respondents

\begin{tabular}{|c|c|c|}
\hline & Frequency & $\%$ \\
\hline \multicolumn{3}{|l|}{ Sex } \\
\hline Male & 118 & 51 \\
\hline Female & 114 & 49 \\
\hline \multicolumn{3}{|l|}{ Age (In Years) } \\
\hline Less Than 23 & 97 & 42 \\
\hline $23-29$ & 79 & 34 \\
\hline $30-36$ & 38 & 16 \\
\hline Above 36 & 18 & 8 \\
\hline \multicolumn{3}{|l|}{ Occupational Status } \\
\hline Salaried & 87 & 38 \\
\hline Housewife & 12 & 5 \\
\hline Student & 117 & 50 \\
\hline Unemployed & 16 & 7 \\
\hline \multicolumn{3}{|l|}{ Preference of digital payment } \\
\hline Yes & 210 & 91 \\
\hline No & 22 & 9 \\
\hline \multicolumn{3}{|l|}{ Started using digital payment } \\
\hline Before demonetization & 167 & 72 \\
\hline After demonetization & 65 & 28 \\
\hline
\end{tabular}

The frequency analysis reveals that $51 \%$ are male $49 \%$ are female. With respect to the age group, $42 \%$ of the respondents are less than $23,34 \%$ goes to $23-29,16 \%$ belongs 30-36 and remaining comes under Above 36. 50\% of the respondents are students, $38 \%$ are salaried and remaining unemployed. $91 \%$ respondents are opined that they prefer to use digital payment method and $72 \%$ of the respondents started using digital payment method before demonetization.

Table - 2: Frequency of using digital payment

\begin{tabular}{|c|c|c|}
\hline \multirow{2}{*}{$\begin{array}{c}\text { Frequency of Using } \\
\text { Digital Payment }\end{array}$} & $\begin{array}{c}\text { Sefore } \\
\text { Demonetization }\end{array}$ & $\begin{array}{c}\text { After } \\
\text { Demonetization }\end{array}$ \\
\cline { 2 - 3 } & $59(25 \%)$ & $98(42 \%)$ \\
\hline Regularly & $108(47 \%)$ & $110(47 \%)$ \\
\hline Sometimes & $65(28 \%)$ & $24(11 \%)$ \\
\hline Rarely &
\end{tabular}

The table shows using digital payment method before demonetization and after demonetization. $47 \%$ of the respondents are occasionally using digital payment method in before and after demonetization, $42 \%$ are regularly using digital payment method after demonetization.

Table - 3: Usage of digital payments in different stages

\begin{tabular}{|c|c|c|c|}
\hline \multirow{2}{*}{$\begin{array}{c}\text { Using Digital } \\
\text { Payment }\end{array}$} & \multicolumn{2}{|c|}{ Started using digital payment } \\
\cline { 2 - 4 } & $\begin{array}{c}\text { Before } \\
\text { Demonetization }\end{array}$ & $\begin{array}{c}\text { After } \\
\text { Demonetization }\end{array}$ & $\begin{array}{c}\text { In Both } \\
\text { the } \\
\text { Stages }\end{array}$ \\
\hline $\begin{array}{c}\text { Internet } \\
\text { Banking }\end{array}$ & $51(22 \%)$ & $59(25 \%)$ & $\begin{array}{c}122 \\
(53 \%)\end{array}$ \\
\hline E-Shopping & $60(26 \%)$ & $43(19 \%)$ & $\begin{array}{c}129 \\
(56 \%)\end{array}$ \\
\hline Point of Sale & $53(23 \%)$ & $68(30 \%)$ & 110 \\
\hline
\end{tabular}

\begin{tabular}{|c|c|c|c|}
\hline Transaction & & & $(47 \%)$ \\
\hline Bill Payments & $48(21 \%)$ & $57(25 \%)$ & $\begin{array}{c}127 \\
(58 \%)\end{array}$ \\
\hline
\end{tabular}

The above table showing that the usage of digital payments in different stages. $58 \%$ of the respondents are using digital payments method to pay their bills in both the stages, $56 \%$ using digital payments method to do E- Shopping both the stages, 53\% using internet banking in both the stages, 58\% using digital payments method to pay their bills in both the stages and $47 \%$ using digital payments method to do the point of sale transaction in both the stages. Based on respondent's opinion, usage of digital payments have increased after demonetization.

Table - 4: Paired t test: Preferred mode of payment before and after demonetization

\begin{tabular}{|c|c|c|c|c|}
\hline \multirow[b]{2}{*}{ Particulars } & Before & After & \multirow[b]{2}{*}{ t-Value } & \multirow[b]{2}{*}{$P$ value } \\
\hline & $\begin{array}{l}\text { Mean } \\
\text { (SD) }\end{array}$ & $\begin{array}{c}\text { Mean } \\
\text { (SD) }\end{array}$ & & \\
\hline Net Banking & $\begin{array}{c}3.72 \\
(1.29)\end{array}$ & $\begin{array}{c}4.09 \\
(1.29)\end{array}$ & 5.64 & $.001^{* * *}$ \\
\hline Debit Card & $\begin{array}{c}4.18 \\
(0.93)\end{array}$ & $\begin{array}{c}4.29 \\
(0.89)\end{array}$ & 1.93 & .054 \\
\hline Credit Card & $\begin{array}{l}2.83 \\
(1.50)\end{array}$ & $\begin{array}{c}3.04 \\
(1.54)\end{array}$ & 3.29 & $.001^{* * *}$ \\
\hline $\begin{array}{c}\text { E-Wallet/ } \\
\text { Mobile app }\end{array}$ & $\begin{array}{c}3.23 \\
(1.27)\end{array}$ & $\begin{array}{c}3.63 \\
(1.28)\end{array}$ & 5.27 & $.001 * *$ \\
\hline Cheque & $\begin{array}{c}2.84 \\
(1.36)\end{array}$ & $\begin{array}{c}2.78 \\
(1.45)\end{array}$ & 1.14 & .254 \\
\hline
\end{tabular}

Note: ** Significant at $1 \%$ level of significance

Since $\mathrm{p}$ value is less than 0.01 the null hypothesis is rejected at $1 \%$ level with regard to Net Banking, Credit Card and E-Wallet/ Mobile app. Hence there is significant difference in mean score of preferred mode of payment before and after demonetization. Based on mean score preferred mode of payment has increased after demonetization. There is no significant difference in mean score of preferred mode of payment before and after demonetization with regard to Debit Card and Cheque. Since $p$ value is greater than 0.05 the null hypothesis is accepted at 5\% level. Based on mean score debit card usage has increased after demonetization and the cheque usage has decreases after demonetization.

Table - 5: Chi Square test: Association between the Genders of the respondents and the Clusters of Digital Payment Problems

\begin{tabular}{|c|c|c|c|c|}
\hline \multirow{2}{*}{ Gender } & \multicolumn{3}{|c|}{ Cluster Number of Case } & \multirow{2}{*}{ Total } \\
\cline { 2 - 4 } & Moderate & Disagree & $\begin{array}{c}\text { Highly } \\
\text { Agree }\end{array}$ & \\
\hline Male & 49 & 25 & 44 & 118 \\
\hline Female & 56 & 21 & 37 & 114 \\
\hline Total & 105 & 46 & 81 & 232 \\
\hline \multicolumn{5}{|c|}{$\begin{array}{c}\text { Chi-Square Value=1.351 } \\
\text { P-value=0.509 } \\
\text { 5\% level of Significance }\end{array}$} \\
\hline
\end{tabular}

Published By: 
The table is inferred that the chi-square value 1.351 and the p-value 0.509 states that the gender of the respondents do not have any association towards the clusters of Digital payment problems at $5 \%$ level of significance. Hence, the null hypothesis accepted. Therefore, there is no association between the Genders of the respondents and the Clusters of Digital Payment Problems.

\section{CONCLUSION AND ITS IMPLICATIONS}

The study shows that after demonetization, usage of the digital payment system has been increased. Digital system is a need in today's society for better development. In the current scenario online transactions are much safer than the past. Transactions can be completed within less time digitally, thus helps in reducing the paper work and associated problems. The scope for the digital system is seen to be increasing day by day and the adoption of internet is also high in India. The study has made a try to know usage pattern of digital payment before and after demonetization. The outcomes of the study show that the usage of E-Wallets, Mobile app, net banking, credit card, and debit card has increased after demonetization and using of cheque has decreased after demonetization. This shows that the people have adapted to the digital payment system because the technology made them with ease.

\section{CONFINES OF THE STUDY AND DIRECTIONS FOR UPCOMING RESEARCH}

We, in our study, attempted to study usage of digital payments pre and post demonetization in Chennai city with a sample size of 232. Hence it will not be appropriate to generalize the finding of the study to the entire state of Tamil Nadu. Moreover, the study has been limited only to the metropolitan city. Future research can be conducted in rural areas of different states to identify their usage patterns. A comparative study can also be conducted between states with regard to usage of digital payments.

\section{REFERENCES}

1. P. Jijin (2019). Has Demonetisation Pushed Digitalisation in India?

2. Some Counter Evidences. Journal of Business Thought, Vol 9, DOI: 10.18311/jbt/2018/21170, April 2018 - March 2019

3. Prasad RajendraByakod, Chaya U., Pooja Kulgude, Abhishek Sharma, Priyanka Singh and Chandra Sen Mazumdar (2018) "A Study on Penetration of Digital Payment System in Selected Areas of Rural Karnataka" Journal of UAS-JMC, Vol 04, Issue 2

4. Shamsher Singh and Ravish Rana (2017) "Study of Consumer Perception of Digital Payment Modes" An open access Internet journal (http://www.icommercecentral.com) Journal of Internet Banking and Commerce, December 2017, vol. 22, no. 3

5. Sudesh Kumar and Ms. Sunandan Bumra(2017). DEMONETIZATION IN INDIA: PRE AND POST EFFECT ON INDIAN INDUSTRY. International Journal of Scientific \& Engineering Research Volume 8 Issue 7, July-2017 266 ISSN $2229-5518$ IJSER $\quad$ (C) 2017 http://www.ijser.org

6. International Conference on "Paradigm Shift in Taxation, Accounting, 12 Page Finance and Insurance"

7. Gangopadhayay (2009) How technology facilitate financial inclusion in India? A discussion paper. Review of Market Integration, 1(2), 223-256

\section{AUTHORS PROFILE}

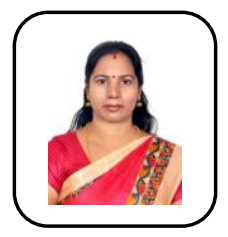

Dr. G. Maheswari, is an Assistant Professor of Commerce at Madras Christian College since 2012. She received her M.Phil. andPh.D degree in commerce from the ManonmaniamSundaranar University, Tirunelveli. She has cleared UGC-NET in the subject of commerce. Her area of interest in research and teaching is Finance. The research contribution of Dr. G.MAHESWARI covers potential research area like investor behaviour in the stock market, financial inclusion, financial literacy, online shopping behaviour etc. she has published 11 research articles in both national and international journals and presented 13 research papers at both national and international conferences and seminars.

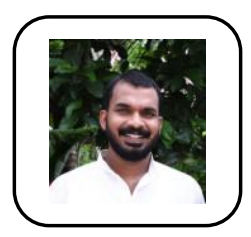

Mr. Justin Thomas Philip, is an Assistant Professor of Commerce at Madras Christian College, Chennai since 2012. He received his M.Com and M.B.A degree from the University of Madras. He has cleared UGC NET in Commerce, Tamil Nadu SET in Commerce and Management and Kerala SET in Commerce. His area of interest in teaching is Accountancy and Marketing. He has published research articles in the areas like Financial Inclusion, Marketing and Digital Payments etc. He has published 3 research articles in both national and international journals and 1 chapter in an edited book. 